\title{
Water-stable lithium ion conducting solid electrolyte of iron and aluminum doped NASICON-type $\mathrm{LiTi}_{2}\left(\mathrm{PO}_{4}\right)_{3}$
}

\author{
P. Zhang ${ }^{\mathrm{a}}$. M. Matsui ${ }^{\mathrm{a}, \mathrm{b}}$, Y. Takeda ${ }^{\mathrm{a}}$, O. Yamamoto ${ }^{\mathrm{a},}{ }^{,}$, and N. Imanishi ${ }^{\mathrm{a}}$ \\ ${ }^{\mathrm{a}}$ Graduate School of Engineering, Mie University, Tsu, Mie, 514-8507, Japan \\ ${ }^{b}$ JST, PRESTO, 4-1-8 Honcho, Kawaguchi, Saitama, 332-0012, Japan
}

\begin{abstract}
High lithium ion conductivity solid electrolytes of $\mathrm{Li}_{1+\mathrm{x}} \mathrm{Fe}_{\mathrm{x}} \mathrm{Ti}_{2-\mathrm{x}}\left(\mathrm{PO}_{4}\right)_{3}$ and $\mathrm{Li}_{1.4} \mathrm{Fe}_{\mathrm{x}} \mathrm{Al}_{0.4-\mathrm{x}} \mathrm{Ti}_{1.6}\left(\mathrm{PO}_{4}\right)_{3} \quad(\mathrm{x}=0-0.4) \quad$ with the NASICON-type structure were synthesized using a precursor prepared by the sol-gel method. The highest electrical conductivity was obtained for the $\mathrm{Li}_{1.4} \mathrm{Fe}_{0.25} \mathrm{Al}_{0.15} \mathrm{Ti}_{1.6}\left(\mathrm{PO}_{4}\right)_{3}$ (LFATP) composition sintered at $1040{ }^{\circ} \mathrm{C}$ for $7 \mathrm{~h}$ in air. The total, grain boundary, and bulk conductivities of the pellet were stable after storage for one month and were $1.01 \times 10^{-3}, 2.17 \times 10^{-3}$ and $1.81 \times 10^{-3} \mathrm{~S} \mathrm{~cm}^{-1}$ at $25{ }^{\circ} \mathrm{C}$, respectively. The contribution of electron (or hole) conductivity to the total conductivity was negligibly small. LFATP was unstable in water, but stable in saturated $\mathrm{LiOH}$ and $\mathrm{LiCl}$ aqueous solution.
\end{abstract}

\section{Introduction}

The lithium-air battery is a very promising power source because it has a far higher theoretical energy density than lithium-ion batteries. Two types of lithium-air batteries, non-aqueous [1] and aqueous [2], have been investigated. The non-aqueous system (3460 $\mathrm{Wh} \mathrm{kg}^{-1}$ ) has higher energy density than the aqueous system $\left(1910 \mathrm{Wh} \mathrm{kg}^{-1}\right)$; however, the non-aqueous system has some serious problems that must still be addressed, such as the corrosion of lithium by water and $\mathrm{CO}_{2}$ ingression when operated in air, precipitation of high resistance reaction products (lithium oxide) on the air electrode, and high polarization during the charge and discharge processes. These problems with the non-aqueous system could be overcome for the aqueous 
system, which was proposed by Visco et al. in 2004 [3]. The key material of the aqueous system is a water-stable lithium ion conducting solid electrolyte, without which the aqueous system could not be realized.

Lithium ion conducting solid electrolytes with various crystalline structures, such as $\mathrm{Li}_{3} \mathrm{~N}$ [4], $\mathrm{Li}_{2} \mathrm{~S}$-based glass [5], NASICON-type $\mathrm{Li}_{1+\mathrm{x}} \mathrm{Al}_{\mathrm{x}} \mathrm{Ti}_{2-\mathrm{x}}\left(\mathrm{PO}_{4}\right)_{3}$ (LATP) [6], garnet-type $\mathrm{Li}_{7} \mathrm{La}_{3} \mathrm{Zr}_{2} \mathrm{O}_{12}$ (LLZ) [7], and perovskite-type $\mathrm{La}_{2 / 3-\mathrm{x}} \mathrm{Li}_{3 \mathrm{x}} \mathrm{TiO}_{3}$ (LLTO) [8] have been investigated extensively. Recently, Kamaya et al. [9] reported a lithium superionic conductor of $\mathrm{Li}_{10} \mathrm{GeP}_{2} \mathrm{~S}_{12}$, which has an extremely high lithium ion conductivity of $1.2 \times 10^{-2} \mathrm{~S} \mathrm{~cm}^{-1}$ at room temperature. However, at present, only three types of high lithium ion conductivity solid electrolytes, LATP, LLZ and LLTO, are known to be stable in an aqueous solution with a high concentration of lithium ions. The electrical conductivity of LLZ, which is stable in contact with lithium metal, is comparable to those of LATP and LLTO, but the Li/LLZ/Li cell is short-circuited after a very short period of polarization at $0.5 \mathrm{~mA} \mathrm{~cm}^{-2}$ and $25^{\circ} \mathrm{C}[10,11]$. The LATP and LLTO electrolytes are unstable in contact with lithium metal $[8,12]$; therefore, an interlayer is required between lithium metal and LATP (and LLTO) for the water-stable lithium electrode. Zhang et al. [13] and Visco et al. [3] have successfully used a lithium conducting polymer electrolyte and $\mathrm{Li}_{3} \mathrm{~N}$ as interlayer materials.

To obtain acceptable cell performance for aqueous lithium-air batteries at a high current density requires a water-stable solid lithium ion conductor with a total conductivity of above $10^{-3} \mathrm{~S} \mathrm{~cm}^{-1}$ at the operation temperature. The ionic conductivity of the NASICON-type $\mathrm{LiTi}_{2}\left(\mathrm{PO}_{4}\right)_{3}$ has been considerably increased by substitution of $\mathrm{Sc}^{3+}, \mathrm{Al}^{3+}, \mathrm{Y}^{3+}, \mathrm{Fe}^{3+}, \mathrm{In}^{3+}$ and $\mathrm{Cr}^{3+}$ for $\mathrm{Ti}^{4+}$, where the highest total conductivity of $7 \times 10^{-4} \mathrm{~S} \mathrm{~cm}^{-1}$ was obtained for $\mathrm{Li}_{1.3} \mathrm{M}_{0.3} \mathrm{Ti}_{1.7}\left(\mathrm{PO}_{4}\right)_{3}(\mathrm{M}=\mathrm{Al}$ and $\mathrm{Sc})$ [14]. High total conductivities of $1.3 \times 10^{-3}$ and $5.08 \times 10^{-3} \mathrm{~S} \mathrm{~cm}^{-1}$ at $25{ }^{\circ} \mathrm{C}$ were reported for the glass ceramic $\mathrm{Li}_{1+\mathrm{x}} \mathrm{Ti}_{2-\mathrm{x}} \mathrm{Al}_{\mathrm{x}}\left(\mathrm{PO}_{4}\right)_{3}$ [15] and $\mathrm{Li}_{1.5} \mathrm{Al}_{0.5} \mathrm{Ge}_{1.5}\left(\mathrm{PO}_{4}\right)_{3}$ [16], respectively. However, the preparation of glass ceramics is somewhat complex and the effect of aging on the conductivity is questionable. The electrical conductivity of the commercialized $\mathrm{Li}_{1+\mathrm{x}+\mathrm{y}} \mathrm{Al}_{\mathrm{x}}(\mathrm{Ti}, \mathrm{Ge})_{2-\mathrm{x}} \mathrm{P}_{3-\mathrm{y}} \mathrm{Si}_{\mathrm{y}} \mathrm{O}_{12}$ (Ohara plate) glass ceramic is $10^{-4} \mathrm{~S} \mathrm{~cm}^{-1}$ at room temperature, while the highest conductivity of LLTO was reported to be $5.7 \times 10^{-4} \mathrm{~S}$ $\mathrm{cm}^{-1}$ at $300 \mathrm{~K}[8]$. We have previously reported the electrical conductivity of sintered pellets of $\mathrm{Li}_{1.4} \underline{\mathrm{Al}}_{0.4} \underline{\mathrm{Ti}}_{1.6-\mathrm{x}} \underline{\mathrm{Ge}}_{\mathrm{x}}\left(\mathrm{PO}_{4}\right)_{3}$ [17]. The electrical conductivity of $\underline{\mathrm{Li}}_{1.4} \underline{\mathrm{Al}}_{0.4} \underline{\mathrm{Ti}}_{1.6}\left(\mathrm{PO}_{4}\right)_{2}$ was enhanced by the substitution of $\mathrm{Ge}^{4+}$ for $\mathrm{Ti}^{4+}$, where the ionic radius of $\mathrm{Ge}^{4+}(0.067 \mathrm{~nm})$ is lower than that of $\mathrm{Ti}^{4+}(0.0745 \mathrm{~nm})$. The highest 
electrical conductivity of $1.29 \times 10^{-3} \mathrm{~S} \mathrm{~cm}^{-1}$ at $25{ }^{\circ} \mathrm{C}$ was obtained for $\underline{\mathrm{Li}_{1.4}} \underline{\mathrm{Al}_{0.4}} \underline{\mathrm{Ti}_{1.4}} \underline{\mathrm{Ge}_{0.2}} \underline{\left.\mathrm{PO}_{4}\right)_{2}}$. The average ionic radius of $\mathrm{Ti}^{4+}$ and $\mathrm{Ge}^{4+}$ in $\mathrm{x}=0.2$ was decreased to $0.0735 \mathrm{~nm}$. In this study, the electrical conductivity behavior of the co-substitution of $\mathrm{Fe}^{3+}$ with a larger ionic radius $(0.0785 \mathrm{~nm})$ and $\mathrm{Al}^{3+}$ with a lower ionic radius $(0.0675 \mathrm{~nm})$ than $\mathrm{Ti}^{4+}(0.0745 \mathrm{~nm})$ [18] for $\mathrm{Ti}$ in $\mathrm{Li}_{1.4} \mathrm{Al}_{0.4} \mathrm{Ti}_{1.6}\left(\mathrm{PO}_{4}\right)_{3}$ was investigated, where the average ionic radius of $\mathrm{Al}^{3+}$ and $\mathrm{Fe}^{3+}$ brings close to the ionic radius of $\mathrm{Ti}^{4+}$. The contribution of electronic conductivity to the total conductivity and the stability of $\mathrm{Li}_{1.4} \mathrm{Fe}_{0.25} \mathrm{Al}_{0.15} \mathrm{Ti}_{1.6}\left(\mathrm{PO}_{4}\right)_{3}$ in water were also examined.

\section{Experimental}

The precursor of $\mathrm{Li}_{1+\mathrm{x}+\mathrm{y}} \mathrm{Al}_{\mathrm{x}} \mathrm{Fe}_{\mathrm{y}} \mathrm{Ti}_{2-\mathrm{x}-\mathrm{y}}\left(\mathrm{PO}_{4}\right)_{3}$ was prepared by the sol-gel method using citric acid, as reported previously [17]. A stoichiometric amount of $\mathrm{Ti}\left(\mathrm{OC}_{4} \mathrm{H}_{9}\right)_{4}$ (Aldrich) was dissolved in ethylene glycol and then added to a $0.2 \mathrm{M}$ aqueous solution of citric acid with continuous stirring with a magnetic stirrer at $120{ }^{\circ} \mathrm{C}$ for $12 \mathrm{~h}$ to obtain a homogeneous solution. After preparation of the gel was completed, stoichiometric amounts of $\mathrm{LiNO}_{3}, \mathrm{Al}\left(\mathrm{NO}_{3}\right)_{3} \cdot 9 \mathrm{H}_{2} \mathrm{O}, \mathrm{Fe}\left(\mathrm{NO}_{3}\right)_{3} \cdot 9 \mathrm{H}_{2} \mathrm{O}$, and $\mathrm{NH}_{4} \mathrm{H}_{2} \mathrm{PO}_{4}$ were added to the gel solution. The molar ratio of citric acid to $\mathrm{Li}^{+}+\mathrm{Al}^{3+}+\mathrm{Fe}^{3+}+$ $\mathrm{Ti}^{4+}$ was 4:1. After a homogeneous solution was formed, the gel was kept at $170{ }^{\circ} \mathrm{C}$ for several hours to allow evaporation of the water and to promote esterification and polymerization. The gel was then heated at $500{ }^{\circ} \mathrm{C}$ for $4 \mathrm{~h}$ to complete the chemical decomposition of nitrates and organic compounds. The black product with residual carbon was ground to a uniformly fine powder using an agate mortar and pestle to increase the surface area of the powder samples before sintering at $800{ }^{\circ} \mathrm{C}$ for chemical reaction and to remove organic residues. The precursor was then ground by wet milling using a planetary mill (Fritsch planetary micro mill) for $15 \mathrm{~h}$ to produce fine powders. The fine powder was isostatically pressed at $150 \mathrm{MPa}$ into a pellet (ca. $12 \mathrm{~mm}$ diameter and $15 \mathrm{~mm}$ thick) and then sintered at various temperatures on a gold sheet to protect the samples from reaction with the alumina refractory board. The stability of the sintered pellets in aqueous solutions was evaluated by immersion into distilled water, saturated $\mathrm{LiCl}$, and saturated $\mathrm{LiOH}$ and $\mathrm{LiCl}$ aqueous solutions at $50{ }^{\circ} \mathrm{C}$ for one week. After immersion in these solutions, the pellets were carefully washed with distilled water and dried in a vacuum at $220^{\circ} \mathrm{C}$ for $20 \mathrm{~h}$ before electrical conductivity and X-ray diffraction (XRD) measurements. 
XRD data were obtained using a diffractometer (Rigaku Rint 2500) with $\mathrm{Cu} \mathrm{K \alpha}$ radiation in the $2 \theta$ range from 10 to $90^{\circ}$ at a scanning step rate of $0.02 \mathrm{~s}^{-1}$. Si powder was used as an internal standard. Scanning electron microscopy (SEM; Hitachi S-486 SEM) observations were conducted and the relative elemental contents of the samples were measured using energy dispersive X-ray spectrometry. The AC impedance of the sintered pellets with sputtered gold electrodes was measured in air using a frequency response analyzer (Solartron 1260) in the temperature range from 20 to $80{ }^{\circ} \mathrm{C}$ and in the frequency range of $0.1 \mathrm{~Hz}$ to $1 \mathrm{MHz}$. The impedance profiles were analyzed to estimate the bulk and grain boundary conductivities using a non-linear instant fit program in the Zview software package. The electron conductivity was estimated using the Hebb-Wagner [19] method for $\mathrm{LiCoO}_{2} /$ electrolyte sample/Au cells. The DC conductivities of the electrolyte samples were examined using non-blocking $\mathrm{LiCoO}_{2} /$ electrolyte sample/ $\mathrm{LiCoO}_{2}$ cells, where the $\mathrm{LiCoO}_{2}$ and $\mathrm{Au}$ electrodes were sputtered onto the pellets.

\section{Results and discussion}

The pressed pellets of $\mathrm{Li}_{1+\mathrm{x}} \mathrm{Fe}_{\mathrm{x}} \mathrm{Ti}_{2-\mathrm{x}}\left(\mathrm{PO}_{4}\right)_{3}$ (LFTP) were sintered at various temperatures for $7 \mathrm{~h}$. The XRD patterns of LFTP with $\mathrm{x}=0.1-0.5$ sintered at 900 and $950{ }^{\circ} \mathrm{C}$ were indexed as the NASICON-type structure, although impurity phases such as $\underline{\mathrm{FePO}}_{4}, \underline{\mathrm{Fe}}_{2} \underline{\mathrm{O}}_{3}$, and $\underline{\mathrm{Ti}}_{\underline{1}} \underline{\mathrm{O}}_{7}$ were also present. The LFTP samples with $\mathrm{x}=0.1,0.2$ and 0.3 sintered at $1000{ }^{\circ} \mathrm{C}$ for $7 \mathrm{~h}$ showed no impurity phases, while an impurity phase of $\underline{\mathrm{FePO}}_{4} \underline{\mathrm{Fe}}_{2} \underline{\mathrm{O}}_{3}$, and $\mathrm{Ti}_{4} \underline{\mathrm{O}}_{7}$ was observed in LFTP with $\mathrm{x}=0.4$ and 0.5 , as shown in Fig. 1 . The impurity phase disappeared for LFTP with $\mathrm{x}=0.4$ when sintered at $1040{ }^{\circ} \mathrm{C}$, but was still observed for LFTP with $\mathrm{x}=0.5$ sintered at the same temperature, as shown in Fig. 1.

Figure 2 shows impedance profiles measured at $25^{\circ} \mathrm{C}$ for LFTP sintered at $1000{ }^{\circ} \mathrm{C}$ for $7 \mathrm{~h}$ as a function of $\mathrm{x}$ and those for LFTP with $\mathrm{x}=0.4$ and 0.5 sintered at $1040{ }^{\circ} \mathrm{C}$ for $7 \mathrm{~h}$. The impedance profiles have a semicircle that is attributed to the grain boundary resistance, the diameter of which indicates the magnitude. The intercept of the semicircle on the real axis at high frequency represents the bulk resistance. The semicircle due to the bulk was not observed, because this was out of the frequency range of the frequency analyzer [20]. The grain boundary resistances for LFTP were significantly dependent on $\mathrm{x}$ in $\mathrm{Li}_{1+\mathrm{x}} \mathrm{Fe}_{\mathrm{x}} \mathrm{Ti}_{2-\mathrm{x}}\left(\mathrm{PO}_{4}\right)_{3}$, while the bulk resistances were increased slightly with increasing $\mathrm{x}$. 
Figure 3 shows the relative densities of the $\mathrm{Li}_{1+\mathrm{x}} \mathrm{Fe}_{\mathrm{x}} \mathrm{Ti}_{2-\mathrm{x}}\left(\mathrm{PO}_{4}\right)_{3}(\mathrm{x}=0-0.5)$ pellets sintered at $1000{ }^{\circ} \mathrm{C}$ for $7 \mathrm{~h}$ as a function of $\mathrm{x}$. The relative densities were calculated from the ratios of the observed densities calculated using the sintered pellet dimensions and weights to those determined from the lattice parameters. The relative densities of the pellets sintered at $1000{ }^{\circ} \mathrm{C}$ were increased by the substitution of $\mathrm{Ti}$ with Fe. The decrease in the grain boundary resistance of the sintered pellets with $\mathrm{x}<0.4$ could be explained by the increase of the relative density. The total electrical conductivities of the as-sintered $\mathrm{Li}_{1.4} \mathrm{Fe}_{0.4} \mathrm{Ti}_{1.6}\left(\mathrm{PO}_{4}\right)_{3}$ were.7.7 $\times 10^{-4} \mathrm{~S} \mathrm{~cm}^{-1}$ at $25{ }^{\circ} \mathrm{C}$, which is higher than that for $\mathrm{Li}_{1.4} \mathrm{Fe}_{0.4} \mathrm{Ti}_{1.6}\left(\mathrm{PO}_{4}\right)_{3}$ at $2.6 \times 10^{-4} \mathrm{~S} \mathrm{~cm}^{-1}$ (at $25^{\circ} \mathrm{C}$ ) reported by Aono et al. [14], which was prepared by conventional solid state reaction and sintered at $1050{ }^{\circ} \mathrm{C}$ for $2 \mathrm{~h}$. The relative density of the $\mathrm{Li}_{1.4} \mathrm{Fe}_{0.4} \mathrm{Ti}_{1.6}\left(\mathrm{PO}_{4}\right)_{3}$ pellet sintered at $1040{ }^{\circ} \mathrm{C}$ for $7 \mathrm{~h}$ was slightly higher $(86.0 \%)$ than that sintered at $1000{ }^{\circ} \mathrm{C}$ for $7 \mathrm{~h}(83.9 \%)$ and the total conductivity was increased to $8.5 \times 10^{-4} \mathrm{~S} \mathrm{~cm}^{-1}$ at $25^{\circ} \mathrm{C}$. This sample exhibited an aging effect on the conductivity, which decreased to $7.31 \times 10^{-4} \mathrm{~S} \mathrm{~cm}^{-1}$ at $25^{\circ} \mathrm{C}$ after one month.

Pressed pellets of the sol-gel precursor for co-doped $\mathrm{Li}_{1.4} \mathrm{Fe}_{\mathrm{x}} \mathrm{Al}_{0.4-\mathrm{x}} \mathrm{Ti}_{1.6}\left(\mathrm{PO}_{4}\right)_{3}$ (LFATP) were sintered at $1040{ }^{\circ} \mathrm{C}$ for $7 \mathrm{~h}$. The total content of $\mathrm{Al}$ and $\mathrm{Ti}$ was fixed at 0.4 because the highest conductivity was observed at $\mathrm{x}=0.4$ in $\mathrm{Li}_{1+\mathrm{x}} \mathrm{Fe}_{\mathrm{x}} \mathrm{Ti}_{2-\mathrm{x}}\left(\mathrm{PO}_{4}\right)_{3}$. Figure 4 shows XRD patterns for the LFATP samples as a function of $\mathrm{x}$. An impurity phase of $\mathrm{AlPO}_{4}$ was observed for $\mathrm{Li}_{1.4} \mathrm{Al}_{0.4} \mathrm{Ti}_{1.6}\left(\mathrm{PO}_{4}\right)_{3}$ sintered at $1040{ }^{\circ} \mathrm{C}$, while all the diffraction lines were indexed according to the NASICON-type structure for LFATP with $\mathrm{x}=0.1-0.4$. Figure 5 shows the change in the lattice parameter with $\mathrm{x}$ in LFATP, where the lattice parameters were calculated using a hexagonal unit cell. The lattice parameters for the a- and $\mathrm{c}$-axis increased with $\mathrm{x}$ because the ionic radius of $\mathrm{Fe}^{3+}(0.0785 \mathrm{~nm})$ is larger than that of $\mathrm{Al}^{3+}(0.0675 \mathrm{~nm})$. Figure 6 shows the relative densities of the LFATP pellets sintered at $1040{ }^{\circ} \mathrm{C}$ for $7 \mathrm{~h}$ as a function of $\mathrm{x}$. The relative densities of the sintered pellets were increased by the substitution of $\mathrm{Al}$ for $\mathrm{Fe}$ up to $\mathrm{x}=0.25$ and then decreased with further substitution. A maximum relative density of $93.6 \%$ was obtained for $\mathrm{Li}_{1.4} \mathrm{Fe}_{0.25} \mathrm{Al}_{0.15} \mathrm{Ti}_{1.6}\left(\mathrm{PO}_{4}\right)_{3}$. The relative density is comparable with that for the high lithium ion conducting solid electrolyte of $\mathrm{Li}_{1.4} \mathrm{Al}_{0.4} \mathrm{Ti}_{1.4} \mathrm{Ge}_{0.2}\left(\mathrm{PO}_{4}\right)_{4}$ reported in our previous paper [17].

The effects of the sintering temperature and period on the electrical conductivity were examined. The impedance profiles for $\mathrm{Li}_{1.4} \mathrm{Fe}_{0.25} \mathrm{Al}_{0.15} \mathrm{Ti}_{1.4}\left(\mathrm{PO}_{4}\right)_{3}$ sintered at various temperatures and for various periods are shown in Fig. 7. The grain boundary 
conductivity of the as-sintered samples was dependent on the sintering temperature and period, while the effect on the bulk conductivity was not significant. The highest total conductivity of $1.19 \times 10^{-3} \mathrm{~S} \mathrm{~cm}^{-1}$ was obtained for the sample sintered at $1040{ }^{\circ} \mathrm{C}$ for $7 \mathrm{~h}$. The high temperature sintering as $1040^{\circ} \mathrm{C}$ and long period sintering as $12 \mathrm{~h}$ may produce a high resistance impurity phase at the grain boundary. The $\mathrm{Li}_{1.4} \mathrm{Al}_{0.4} \mathrm{Ti}_{1.6-\mathrm{x}} \mathrm{Ge}_{\mathrm{x}}\left(\mathrm{PO}_{4}\right)_{3}$ system exhibited a significant aging effect with respect to the conductivity, where the total electrical conductivity of $2.25 \times 10^{-3} \mathrm{~S} \mathrm{~cm}^{-1}$ at $25{ }^{\circ} \mathrm{C}$ decreased to the a stable conductivity of $1.29 \times 10^{-3} \mathrm{~S} \mathrm{~cm}^{-1}$ after one month storage [17], Therefore, the impedance of the LFATP samples sintered at $1040{ }^{\circ} \mathrm{C}$ for $7 \mathrm{~h}$ was measured after storage for one month at room temperature in a dry box. Figure 8 and 9 show the impedance profiles and the compositional dependence of the total, bulk, and grain boundary conductivities at $25{ }^{\circ} \mathrm{C}$, respectively. The highest total conductivity of $1.01 \times 10^{-3} \mathrm{~S} \mathrm{~cm}^{-1}$ at $25{ }^{\circ} \mathrm{C}$ was observed for $\mathrm{Li}_{1.4} \mathrm{Fe}_{0.25} \mathrm{Al}_{0.15} \mathrm{Ti}_{1.6}\left(\mathrm{PO}_{4}\right)_{3}$. The compositional dependence suggests that the grain boundary conductivity is changed significantly with $\mathrm{x}$, which corresponds to the relative density of the sintered sample. Maximum bulk and grain boundary conductivities of $1.80 \times 10^{-3}$ and $2.17 \times 10^{-3}$ $\mathrm{S} \mathrm{cm}^{-1}$ were obtained for $\mathrm{x}=0.25$. The average ionic radius of $\mathrm{Al}^{3+}$ and $\mathrm{Fe}^{3+}$ in $\mathrm{x}=0.25$ is $0.0742 \mathrm{~nm}$, which is close to the ionic radius of $\mathrm{Ti}^{4+}(0.0745 \mathrm{~nm})$. A similar result was reported for the conductivity enhancement of $\mathrm{ZrO}_{2}$ by the substitution of $\mathrm{Zr}^{4+}$ for $\mathrm{M}^{3+}$ ions ( $\mathrm{M}=$ lanthanide), where the closest ionic radius to $\mathrm{Zr}^{4+}$ was that of $\mathrm{Sc}^{3+}$, which showed the highest oxide ion conductivity [21]. This behavior could be explained by the interaction between ionic vacancies produced by the substitution of $\mathrm{Zr}^{4+}$ for $\mathrm{M}^{3+}$ and by the structural effect [22]. The bulk $\left(\sigma_{\mathrm{b}}\right)$ and grain boundary $\left(\sigma_{\mathrm{gb}}\right)$ conductivities of $\mathrm{Li}_{1.4} \mathrm{Fe}_{0.25} \mathrm{Al}_{0.15} \mathrm{Ti}_{1.6}\left(\mathrm{PO}_{4}\right)_{3}$ are slightly lower than those of the as-sintered $\mathrm{Li}_{1.4} \mathrm{Al}_{0.4} \mathrm{Ti}_{1.4} \mathrm{Ge}_{0.2}\left(\mathrm{PO}_{4}\right)_{3}\left(\sigma_{\mathrm{b}}=2.01 \times 10^{-3}\right.$ and $\sigma_{\mathrm{gb}}=2.88 \times 10^{-3} \mathrm{~S} \mathrm{~cm}^{-1}$ at $25^{\circ} \mathrm{C}$ ). The effect of aging on the electrical conductivity of LFATP was not as severe as that observed for the $\mathrm{Li}_{1.4} \mathrm{Al}_{0.4} \mathrm{Ti}_{1.6-\mathrm{x}} \mathrm{Ge}_{\mathrm{x}}\left(\mathrm{PO}_{4}\right)_{3}$ system. The activation energies for the bulk $\left(\mathrm{E}_{\mathrm{b}}\right)$ and grain boundary $\left(\mathrm{E}_{\mathrm{gb}}\right)$ conductivities of $\mathrm{Li}_{1.4} \mathrm{Fe}_{0.25} \mathrm{Al}_{0.15} \mathrm{Ti}_{1.6}\left(\mathrm{PO}_{4}\right)_{3}$ were calculated to be 17.0 and $43.9 \mathrm{~kJ} \mathrm{~mol}^{-1}$, respectively, from their temperature dependence in the range from 25 to $80{ }^{\circ} \mathrm{C}$. These activation energies are lower than those for $\mathrm{Li}_{1.4} \mathrm{Al}_{0.4} \mathrm{Ti}_{1.6}\left(\mathrm{PO}_{4}\right)_{3} \quad\left(\mathrm{E}_{\mathrm{b}}=21.1 \mathrm{~kJ}\right.$ mol. ${ }^{-1}$ and $\left.\mathrm{E}_{\mathrm{gb}}=60.4\right)$ and $\mathrm{Li}_{1.4} \mathrm{Al}_{0.4} \mathrm{Ti}_{1.4} \mathrm{Ge}_{0.2}\left(\mathrm{PO}_{4}\right)_{3}\left(\mathrm{E}_{\mathrm{b}}=20.2 \mathrm{~kJ} \mathrm{~mol}^{-1}\right.$ and $\left.\mathrm{E}_{\mathrm{gb}}=55 \mathrm{~kJ} \mathrm{~mol}^{-1}\right)$ [17].

The lithium ion conducting solid electrolyte for the protective layer in the water-stable lithium electrode for lithium-air batteries should be stable in aqueous 
solutions with saturated $\mathrm{LiOH}$ in addition to having high lithium ion conductivity, because the reaction product of the Li-air cell is $\mathrm{LiOH}$. The stability of the $\mathrm{Li}_{1+\mathrm{x}+\mathrm{y}} \mathrm{Al}_{\mathrm{x}}(\mathrm{Ti}, \mathrm{Ge})_{2-\mathrm{x}} \mathrm{Si}_{\mathrm{y}} \mathrm{P}_{3} \mathrm{O}_{12}$ glass ceramic (Ohara plate) in aqueous solutions has been extensively studied by Imanishi and co-workers [10,12]. The glass ceramic decomposes in a strong acid solution and dissolves in strong alkaline solution. However, Shimonishi et al. reported that the glass ceramic is stable in saturated $\mathrm{LiCl}$ and $\mathrm{LiOH}$ aqueous solution, the $\mathrm{pH}$ value of which was around 9, due to the low dissociation of $\mathrm{LiOH}$ to ions in the presence of a high $\mathrm{Li}^{+}$ion content [23]. The stability of $\mathrm{Li}_{1.4} \mathrm{Fe}_{0.25} \mathrm{Al}_{0.15} \mathrm{Ti}_{1.6}\left(\mathrm{PO}_{4}\right)_{3}$ in saturated $\mathrm{LiOH}$ and $\mathrm{LiCl}$ aqueous solution was examined. The XRD patterns of $\mathrm{Li}_{1.4} \mathrm{Fe}_{0.25} \mathrm{Al}_{0.15} \mathrm{Ti}_{1.6}\left(\mathrm{PO}_{4}\right)_{3}$ immersed in distilled water, saturated $\mathrm{LiCl}$ aqueous solution, and saturated $\mathrm{LiCl}$ and $\mathrm{LiOH}$ aqueous solution at $50{ }^{\circ} \mathrm{C}$ for one week revealed no impurity phases and there was no change in the ratio of the diffraction peaks. However, the impedance profiles showed a change after immersion in these solutions, as shown in Fig. 10. The grain boundary resistance of $\mathrm{Li}_{1.4} \mathrm{Fe}_{0.25} \mathrm{Al}_{0.15} \mathrm{Ti}_{1.6}\left(\mathrm{PO}_{4}\right)_{3}$ immersed in distilled water increased significantly from 93 to $480 \Omega \mathrm{cm}^{2}$, and the bulk resistance also increased from 133.5 to $221.7 \Omega \mathrm{cm}^{2}$. These increases in bulk and grain boundary resistance could be explained by the ion exchange of $\mathrm{Li}^{+}$and $\mathrm{H}^{+}$observed in $\mathrm{Li}_{3 x} \mathrm{La}_{2 / 3} \mathrm{TiO}_{3}$ [24] and $\mathrm{Li}_{7} \mathrm{La}_{3} \mathrm{Sn}_{2} \mathrm{O}_{12}$ [25]. The mechanical strength of the pellet was also reduced by immersion in distilled water at $50{ }^{\circ} \mathrm{C}$ for one week. However, the grain boundary and bulk resistances of $\mathrm{Li}_{1.4} \mathrm{Fe}_{0.25} \mathrm{Al}_{0.15} \mathrm{Ti}_{1.6}\left(\mathrm{PO}_{4}\right)_{3}$ immersed in saturated $\mathrm{LiCl}$ aqueous solution and saturated $\mathrm{LiCl}$ and $\mathrm{LiOH}$ aqueous solution were significantly decreased. The total conductivities of $\mathrm{Li}_{1.4} \mathrm{Fe}_{0.25} \mathrm{Al}_{0.15} \mathrm{Ti}_{1.6}\left(\mathrm{PO}_{4}\right)_{3}$ immersed in saturated $\mathrm{LiCl}$ aqueous solution and saturated $\mathrm{LiCl}$ and $\mathrm{LiOH}$ aqueous solution and then measured in the ambient atmosphere were increased from $1.19 \times 10^{-3} \mathrm{~S} \mathrm{~cm}^{-1}$ to $3.44 \times 10^{-3}$ and $4.35 \times 10^{-3}$ $\mathrm{S} \mathrm{cm}^{-1}$, respectively. The conductivities of the sample stored in a dry glove box (dew point of ca. $-80{ }^{\circ} \mathrm{C}$ ) for several hours was decreased to the almost same value as that observed for the pristine sample. A similar enhancement of conductivity by immersion in saturated $\mathrm{LiCl}$ aqueous solution was reported for LATP by Takahashi et al. [26]. The conductivity enhancement was explained by the formation of $\mathrm{LiCl} \cdot \mathrm{H}_{2} \mathrm{O}$ at the grain boundary. Approximately $0.16 \mathrm{wt} \% \mathrm{Cl}$ was detected by EDX analysis in $\mathrm{Li}_{1.4} \mathrm{Fe}_{0.25} \mathrm{Al}_{0.15} \mathrm{Ti}_{1.6}\left(\mathrm{PO}_{4}\right)_{3}$ that was immersed in saturated $\mathrm{LiOH}$ and $\mathrm{LiCl}$. Therefore, the conductivity enhancement in the present study could also be explained by the formation of $\mathrm{LiCl} \cdot \mathrm{H}_{2} \mathrm{O}$ at the grain boundary, and it was concluded that 
$\mathrm{Li}_{1.4} \mathrm{Fe}_{0.25} \mathrm{Al}_{0.15} \mathrm{Ti}_{1.6}\left(\mathrm{PO}_{4}\right)_{3}$ is stable in saturated $\mathrm{LiOH}$ and $\mathrm{LiCl}$ aqueous solution.

The low electron (and/or hole) transport number in the solid electrolyte is an important requirement for use of the electrolyte in batteries. The electronic conductivity of $\mathrm{Li}_{1.4} \mathrm{Fe}_{0.25} \mathrm{Al}_{0.15} \mathrm{Ti}_{1.6}\left(\mathrm{PO}_{4}\right)_{3}$ was estimated using the Hebb-Wagner method [25] for the $\mathrm{LiCoO}_{2} / \mathrm{Li}_{1.4} \mathrm{Fe}_{0.25} \mathrm{Al}_{0.15} \mathrm{Ti}_{1.6}\left(\mathrm{PO}_{4}\right)_{3} / \mathrm{Au}$ cell, where $\mathrm{LiCoO}_{2}$ was used as the cathode to fixed the lithium potential, because $\mathrm{Li}_{1.4} \mathrm{Fe}_{0.25} \mathrm{Al}_{0.15} \mathrm{Ti}_{1.6}\left(\mathrm{PO}_{4}\right)_{3}$ is unstable in contact with lithium metal. A small direct current was passed through the cell and the steady cell voltage was measured as a function of the current density at $25{ }^{\circ} \mathrm{C}$. Figure 11 shows voltage vs. polarization period curves for the $\mathrm{LiCoO}_{2} / \mathrm{Li}_{1.4} \mathrm{Fe}_{0.25} \mathrm{Al}_{0.15} \mathrm{Ti}_{1.6}\left(\mathrm{PO}_{4}\right)_{3} / \mathrm{Au}$ cell as a function of the applied voltage. After application of a voltage through the cell, the current will get to steady state as the ionic current is stopped with an ion blocking electrode. The electronic conductivity of sample can then be obtained from the Wagner relation:

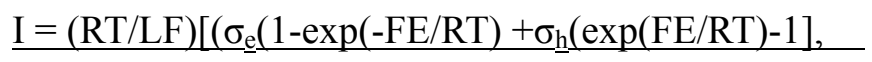

where $\sigma_{\mathrm{h}}$ and $\sigma_{\mathrm{e}}$ are hole and electron conductivity, respectively, I is the current density, $\mathrm{R}$ is the gas constant, $\mathrm{F}$ is the Faraday constant, $\mathrm{T}$ is the absolute temperature, $\underline{L}$ is the thickness of the sample, and $E$ is the applied voltage. However, the current-voltage curves do not obey the Wagner equation. The deviation from the Wagner equation may be due to the potential change of the $\mathrm{LiCoO}_{2}$ electrode, because we could not use lithium metal with a constant lithium activity. The electronic conductivity at $25{ }^{\circ} \mathrm{C}$ was estimated from the current and steady state cell voltage as $2.5 \times 10^{-7} \mathrm{~S} \mathrm{~cm}^{-1}$ at $0.4 \mathrm{~V}$ and $8.8 \times 10^{-7} \mathrm{~S} \mathrm{~cm}^{-1}$ at $1.14 \mathrm{~V}$. Therefore, it was concluded that the contribution of electronic conductivity to the total conductivity is very low.

The de conductivity of $\mathrm{Li}_{1.4} \mathrm{Fe}_{0.25} \mathrm{Al}_{0.15} \mathrm{Ti}_{1.6}\left(\mathrm{PO}_{4}\right)_{3}$ was measured using the lithium ion non-blocking $\mathrm{Au} / \mathrm{LiCoO}_{2} / \mathrm{LFATP} / \mathrm{LiCoO}_{2} / \mathrm{Au}$ cell in open air, because in some cases the impedance profile cannot cover the behavior in the low frequency range. $\mathrm{Li}_{1.4} \mathrm{Fe}_{0.25} \mathrm{Al}_{0.15} \mathrm{Ti}_{1.6}\left(\mathrm{PO}_{4}\right)_{3}$ was determined to be unstable in contact with lithium metal; therefore, $\mathrm{LiCoO}_{2}$ was used as the non-blocking electrode. $\mathrm{LiCoO}_{2}$ is known as a mixed electron and lithium ion conductor. The lithium ion conductivity of $\mathrm{LiCoO}_{2}$ is approximately $10^{-7} \mathrm{~S} \mathrm{~cm}^{-1}$ [27]. $\mathrm{LiCoO}_{2}$ films (ca. $10 \mu \mathrm{m}$ thick) were sputtered on both sides of the $\mathrm{Li}_{1.4} \mathrm{Fe}_{0.25} \mathrm{Al}_{0.15} \mathrm{Ti}_{1.6}\left(\mathrm{PO}_{4}\right)_{3}$ pellet. The change in the cell voltage with time was measured as a function of the applied current at $25^{\circ} \mathrm{C}$, and typical results are shown in Fig. 12. Stable cell voltages were observed at $0.4 \mathrm{~mA} \mathrm{~cm}{ }^{-2}$. The dc conductivity calculated from the cell voltage vs. current density curves was 
approximately $500 \Omega$, which is higher than the total cell resistance of $109 \Omega \mathrm{cm}^{2}$ and the interface resistance of $55 \Omega \mathrm{cm}^{2}$ estimated from the impedance profile. The high dc resistance may be due to the low lithium ion conductivity of $\mathrm{LiCoO}_{2}$ and to electrode polarization. Consequently, $\mathrm{Li}_{1.4} \mathrm{Fe}_{0.25} \mathrm{Al}_{0.15} \mathrm{Ti}_{1.6}\left(\mathrm{PO}_{4}\right)_{3}$ could be considered to be lithium ion conducting solid electrolyte. The low interface resistance between $\mathrm{Li}_{1.4} \mathrm{Fe}_{0.25} \mathrm{Al}_{0.15} \mathrm{Ti}_{1.6}\left(\mathrm{PO}_{4}\right)_{3}$ and $\mathrm{LiCoO}_{2}$ is attractive for its use as an electrolyte in an all-solid-state battery, because some lithium conducting solid electrolytes have a high interface resistance between the solid electrolyte and the electrode [28].

\section{Conclusion}

NASICON-type lithium ion conducting solid electrolytes, $\mathrm{Li}_{1.4} \mathrm{Fe}_{\mathrm{x}} \mathrm{Al}_{0.4-\mathrm{x}} \mathrm{Ti}_{1.6}\left(\mathrm{PO}_{4}\right)_{3}$ $(\mathrm{x}=0-0.4)$, were prepared from a sol-gel precursor with sintering up to $1040{ }^{\circ} \mathrm{C}$ for 7 h. The highest total conductivity of $1.01 \times 10^{-3} \mathrm{~S} \mathrm{~cm}^{-1}$ at $25{ }^{\circ} \mathrm{C}$ was observed for $\mathrm{Li}_{1.4} \mathrm{Fe}_{0.25} \mathrm{Al}_{0.15} \mathrm{Ti}_{1.6}\left(\mathrm{PO}_{4}\right)_{3}$ after storage for one month at room temperature in a dry box. The grain boundary conductivity of as-sintered $\mathrm{Li}_{1.4} \mathrm{Fe}_{0.25} \mathrm{Al}_{0.15} \mathrm{Ti}_{1.6}\left(\mathrm{PO}_{4}\right)_{3}$ did not show a significant aging effect. The contribution of electron (or hole) conductivity was negligible with respect to the total conductivity. $\mathrm{Li}_{1.4} \mathrm{Fe}_{0.25} \mathrm{Al}_{0.15} \mathrm{Ti}_{1.6}\left(\mathrm{PO}_{4}\right)_{3}$ showed a significant increase in resistance by immersion in distilled water; however, that immersed in saturated $\mathrm{LiOH}$ and $\mathrm{LiCl}$ aqueous solution showed a significant decrease of the bulk resistance. The decrease in resistance could explained by the formation of a conductive phase of $\mathrm{LiOH} \cdot \mathrm{H}_{2} \mathrm{O}$ at the grain boundary under a wet atmosphere. It has been concluded that $\mathrm{Li}_{1.4} \mathrm{Fe}_{0.25} \mathrm{Al}_{0.15} \mathrm{Ti}_{1.6}\left(\mathrm{PO}_{4}\right)_{3}$ is a promising candidate for the protective layer of the lithium electrode in aqueous lithium-air batteries, because it has high lithium ion conductivity and stability in saturated LiOH and $\mathrm{LiCl}$ aqueous solution. In addition, $\mathrm{Li}_{1.4} \mathrm{Fe}_{0.25} \mathrm{Al}_{0.15} \mathrm{Ti}_{1.6}\left(\mathrm{PO}_{4}\right)_{3}$ may be used as the electrolyte for all solid state lithium batteries because of its excellent compatibility with the typical cathode material of $\mathrm{LiCoO}_{2}$ for lithium-ion batteries.

\section{Acknowledgment}

This study was supported by Japan Science and Technology Agency (JST) under the "Advanced Low Carbon Technology Research and Development Program" 


\section{References}

[1] T. Ogasawara, A. Debart, M. Holzapfel, P. Novak and P. G. Bruce, J. Am. Chem. Soc., 128 (2006) 1390.

[2] T. Zhang, N. Imanishi, S. Hasegawa, A. Hirano, J. Xie, Y. Takeda, O. Yamamoto and N. Sammes, J. Electrochem. Soc., 155 (2008) A965.

[3] S. J. Visco, B. Katz, L. C. D. Jonghe, M. Y. Chu, 12th International Meeting on Lithium Batteries, Nara, Japan, 2004.

[4] U. V. Alpen, A. Rabenau and G. H. Talat, Apply. Phys. Lett., 30 (1977) 621.

[5] H. Y.-P. Hong, Mat. Res. Bull., 13 (1978) 117.

[6] H. Aono, E. Shugimoto, Y. Sadaoka, N. Imanaka, and G. Adachi, J. Electrochem. Soc., 136 (1989) 590.

[7] R. Murugen, V. Thangadurai, and W. Weppner, Angew. Chem. Int. Ed., 46 (2007) 7778 .

[8] Y. Inaguma, L. Chen, M. Ito, T. Nakamura, T. Uchida, and M. Wakihara, Solid State Commun., 86 (1993) 689.

[9] N. Kamaya, K. Homma, Y. Yamakawa, M. Hirayama, R. Kanno, M. Yonemura, T.

Kamiyama, Y. Kato, S. Hama, K. Kawamoto, and A. Mitsui, Nature Mat., 10 (2011), 682.

[10] K. Ishiguro, Y. Nakata, M. Matsui, I. Uechi, Y. Takeda, O. Yamamoto, and N. Imanishi, J. Electrochem. Soc., 160 (2013) A1684.

[11] R. Sudo, Y. Nakata, M. Matsui, A. Hirano, Y. Takeda, O. Yamamoto, and N, Imanishi, Solid State Ionics, in press.

[12] N. Imanishi, S. Hasegawa, T. Zhang, A. Hirano, Y. Takeda, and O. Yamamoto, J. Power Sources, 185 (2008) 1392.

[13] T. Zhang, N. Imanishi, Y. Shimonishi, A. Hirano, Y. Takeda, and O. Yamamoto, J. Electrochem. Soc., 157 (2010) A214.

[14] H. Aono, E. Sugimoto, Y. Sadaoka, N. Imanaka, and G. Adachi, J. Electrochem. Soc., 137 (1990) 1023.

[15] J. Fu, Solid State Ionics, 96 (1997) 195.

[16] J. S. Thokchom and B. Kumar, J. Power Sources, 185 (2008) 480.

[17] P. Zhang, M. Matsui, A. Hirano, Y. Takeda, O. Yamamoto, and N. Imanishi, Solid State Ionics, 253 (2013) 175. 
[18] R. D. Shannon, Acta Crystallogr., A32 (1976) 751.

[19] J. Wagner and C. Wagner, J. Chem. Phys., 26 (1957) 1597.

[20] P. G. Bruce and A. R. West, J. Electrochem. Soc., 136 (1983) 662.

[21] Y. Arachi, H. Sakai, O. Yamamoto, Y. Takeda, N. and Imanishi, Solid State Ionics, 121 (1999) 133.

[22] J. K. Kilner and R. J. Brock, Solid State Ionics, 6 (1982) 237.

[23] Y. Shimonishi, T. Zhang, N. Imanishi, D. Im, D.-J. Lee, A. Hirano, Y. Takeda, O. Yamamoto, and N. Sammes, J. Power Sources, 196 (2011) 5128.

[24] O. Bohnke, Q. N. Pham, A. Boulant, J. Slakus, M. Barr, Solid State Ionics, 188 (2011) 144.

[25] C. Galven, J. L. Fourquest, M.-P. Crosmeir-Lopez, L. Le Berre, Chem. Mat., 23 (2011) 1892.

[26] K. Takahashi, J. Ohmura, D. Im, D. J. Lee, T. Zhang, N. Imanishi, A. Hirano, M. B. Phillipps, Y. Takeda, and O. Yamamoto, J, Electrochem. Soc., 159 (2012) A342.

[27] Y.-H. Jang, B. J. Neudecker, N. J. Dudney, Electrochem. Solid State Lett., 4 (2001) A74.

[28] N. Ohta, K. Takada, L. Zhang, R. Ma, M. Osada, T. Sasaki, Adv. Mater., 18 (2006) 2226. 
Figure captions

Fig. 1. XRD patterns of $\mathrm{Li}_{1+\mathrm{x}} \mathrm{Fe}_{\mathrm{x}} \mathrm{Ti}_{2-\mathrm{x}}\left(\mathrm{PO}_{4}\right)_{3}(\mathrm{x}=0-0.5)$ sintered at 1000 and $1040{ }^{\circ} \mathrm{C}$ for $7 \mathrm{~h}$.

Fig. 2. Impedance profiles measured at $25^{\circ} \mathrm{C}$ for $\mathrm{Au} / \mathrm{Li}_{1+\mathrm{x}} \mathrm{Fe}_{\mathrm{x}} \mathrm{Ti}_{2-\mathrm{x}}\left(\mathrm{PO}_{4}\right)_{3}(\mathrm{x}=0-0.5) / \mathrm{Au}$ sintered at 1000 and $1040{ }^{\circ} \mathrm{C}$ for $7 \mathrm{~h}$.

Fig. 3. Relative density of the $\mathrm{Li}_{1+\mathrm{x}} \mathrm{Fe}_{\mathrm{x}} \mathrm{Ti}_{2-\mathrm{x}}\left(\mathrm{PO}_{4}\right)_{3}(\mathrm{x}=0-0.5)$ pellets sintered at $1000{ }^{\circ} \mathrm{C}$ for $7 \mathrm{~h}$.

Fig. 4. XRD patterns for $\mathrm{Li}_{1.4} \mathrm{Fe}_{\mathrm{x}} \mathrm{Al}_{0.4-\mathrm{x}} \mathrm{Ti}_{1.6}\left(\mathrm{PO}_{4}\right)_{3}(\mathrm{x}=0-0.4)$ sintered at $1040{ }^{\circ} \mathrm{C}$ for 7 h.

Fig. 5. Room temperature lattice parameters as a function of. $x$ for $\mathrm{Li}_{1.4} \mathrm{Fe}_{\mathrm{x}} \mathrm{Al}_{0.4-\mathrm{x}} \mathrm{Ti}_{1.6}\left(\mathrm{PO}_{4}\right)_{3}(\mathrm{x}=0-0.4)$ sintered at $1040{ }^{\circ} \mathrm{C}$ for $7 \mathrm{~h}$.

Fig. 6. Relative density of the $\mathrm{Li}_{1.4} \mathrm{Fe}_{\mathrm{x}} \mathrm{Al}_{0.4-\mathrm{x}} \mathrm{Ti}_{1.6}\left(\mathrm{PO}_{4}\right)_{3}(\mathrm{x}=0-0.4)$ pellets sintered at $1040{ }^{\circ} \mathrm{C}$ for $7 \mathrm{~h}$.

Fig. 7. Impedance profiles measured at $25^{\circ} \mathrm{C}$ for $\mathrm{Au} / \mathrm{Li}_{1.4} \mathrm{Fe}_{0.25} \mathrm{Al}_{0.15} \mathrm{Ti}_{1.4}\left(\mathrm{PO}_{4}\right)_{3} / \mathrm{Au}$ : (a) sintered at various temperatures for $6 \mathrm{~h}$ and (b) sintered at $1040{ }^{\circ} \mathrm{C}$ for various periods.

Fig. 8. Impedance profiles at $25{ }^{\circ} \mathrm{C}$ for the $\mathrm{Au} / \mathrm{Li}_{1.4} \mathrm{Fe}_{\mathrm{x}} \mathrm{Al}_{0.4-\mathrm{x}} \mathrm{Ti}_{1.6}\left(\mathrm{PO}_{4}\right)_{3}(\mathrm{x}=0-0.4) / \mathrm{Au}$ cell stored at room temperature for one month.

Fig. 9. Bulk, grain boundary and total conductivities measured at $25{ }^{\circ} \mathrm{C}$ of the $\mathrm{Li}_{1.4} \mathrm{Fe}_{\mathrm{x}} \mathrm{Al}_{0.4-\mathrm{x}} \mathrm{Ti}_{1.6}\left(\mathrm{PO}_{4}\right)_{3} \quad(\mathrm{x}=0-0.4)$ sintered at $1040{ }^{\circ} \mathrm{C}$ for $7 \mathrm{~h}$ stored at room temperature for one month.

Fig. 10. Impedance profiles at $25^{\circ} \mathrm{C}$ for $\mathrm{Au} / \mathrm{Li}_{1.4} \mathrm{Fe}_{0.25} \mathrm{Al}_{0.15} \mathrm{Ti}_{1.6}\left(\mathrm{PO}_{4}\right)_{3} / \mathrm{Au}$ : (a) pristine 
$\mathrm{Li}_{1.4} \mathrm{Fe}_{0.25} \mathrm{Al}_{0.15} \mathrm{Ti}_{1.6}\left(\mathrm{PO}_{4}\right)_{3}$, and $\mathrm{Li}_{1.4} \mathrm{Fe}_{0.25} \mathrm{Al}_{0.15} \mathrm{Ti}_{1.6}\left(\mathrm{PO}_{4}\right)_{3}$ immersed in (b) water, (c) saturated $\mathrm{LiCl}$ aqueous solution, and (d) saturated $\mathrm{LiCl}$ and $\mathrm{LiOH}$ aqueous solution at $50{ }^{\circ} \mathrm{C}$ for one week.

Fig. 11. Current vs. voltage characteristics for the $\mathrm{LiCoO}_{2} / \mathrm{Li}_{1.4} \mathrm{Fe}_{0.25} \mathrm{Al}_{0.15} \mathrm{Ti}_{1.6}\left(\mathrm{PO}_{4}\right)_{3} / \mathrm{Au}$ cell at $25^{\circ} \mathrm{C}$.

Fig. 12. Cell voltage vs. polarization period curves at $25{ }^{\circ} \mathrm{C}$ as a function of current density. 
Fig. 1

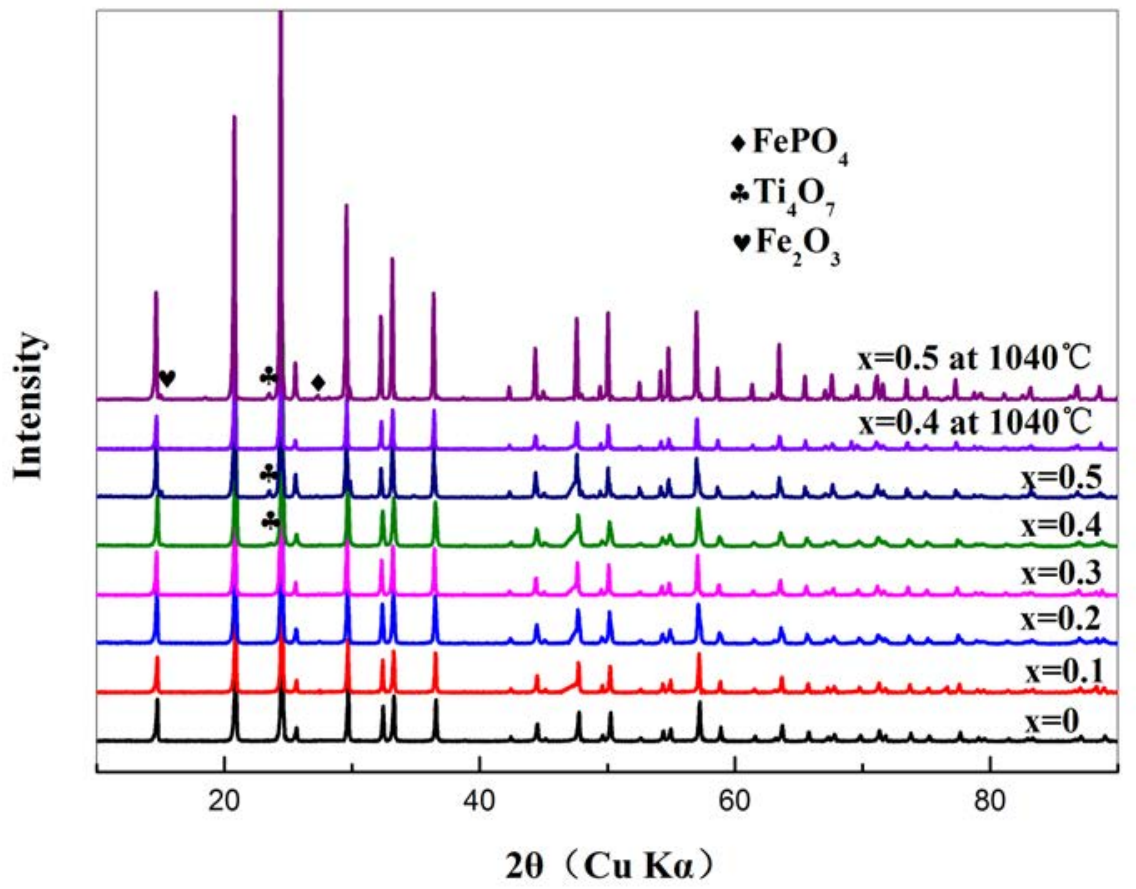


Fig. 2

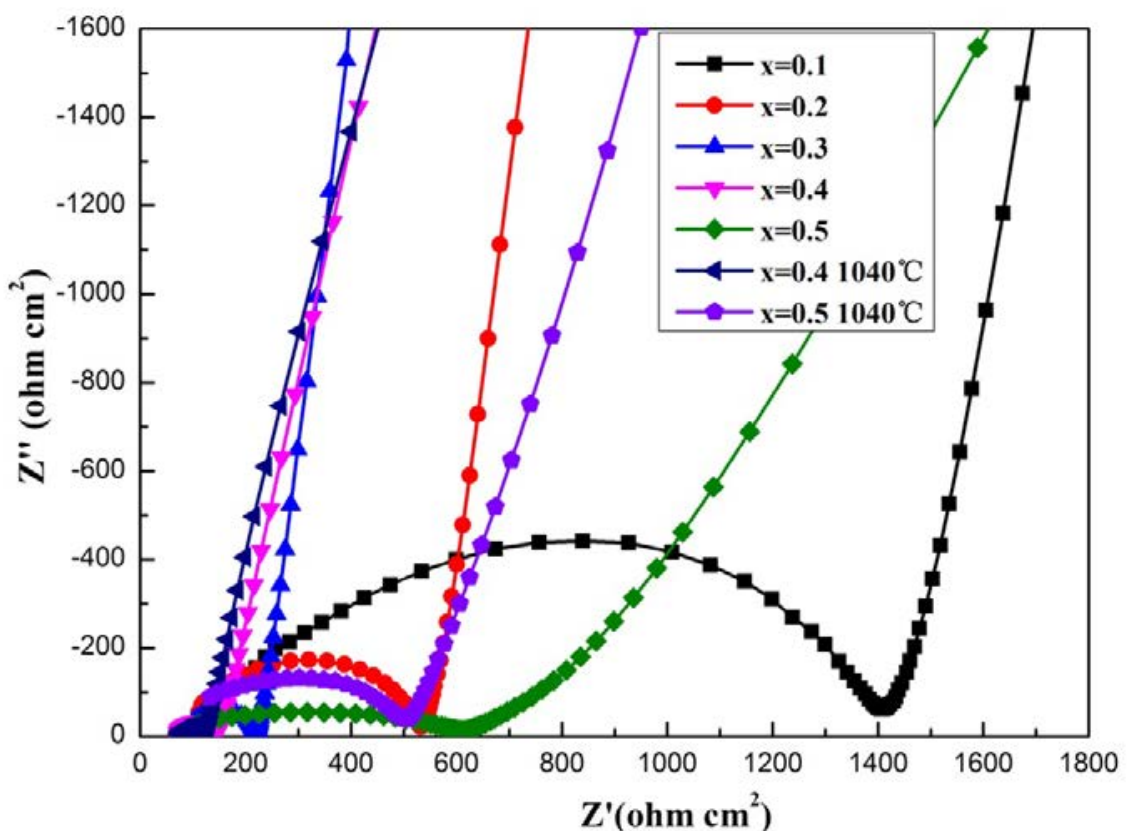


Fig. 3

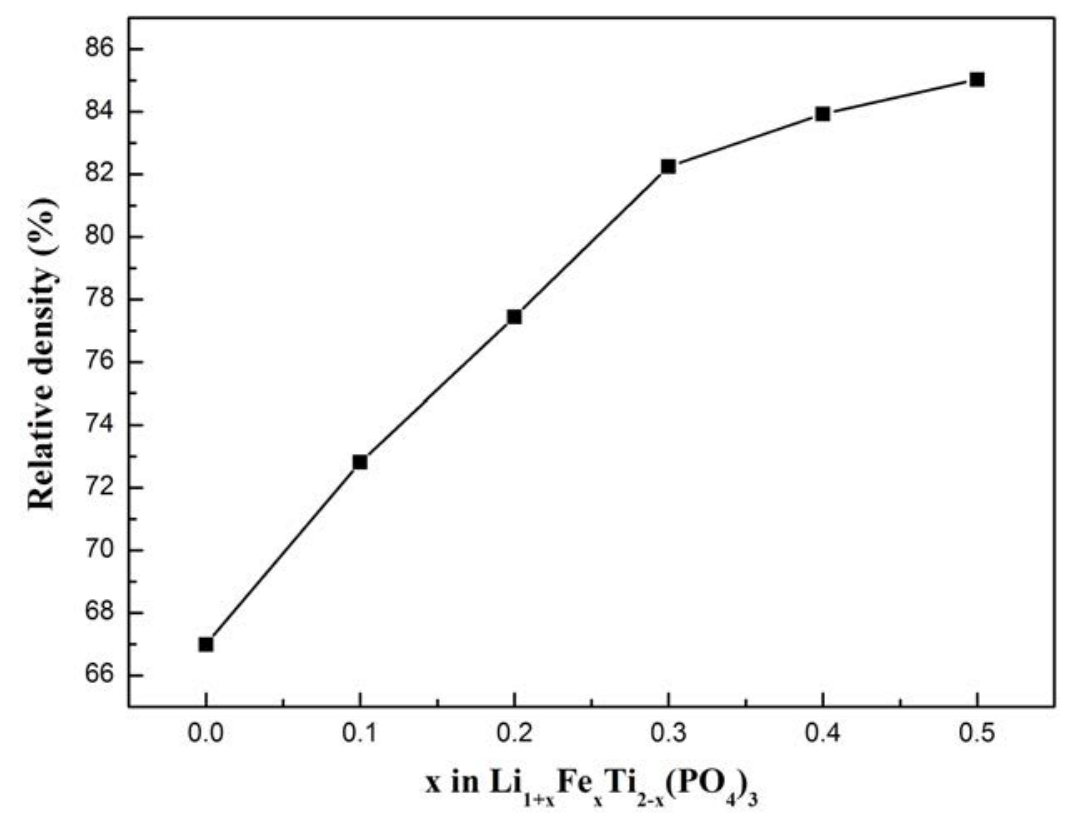


Fig. 4

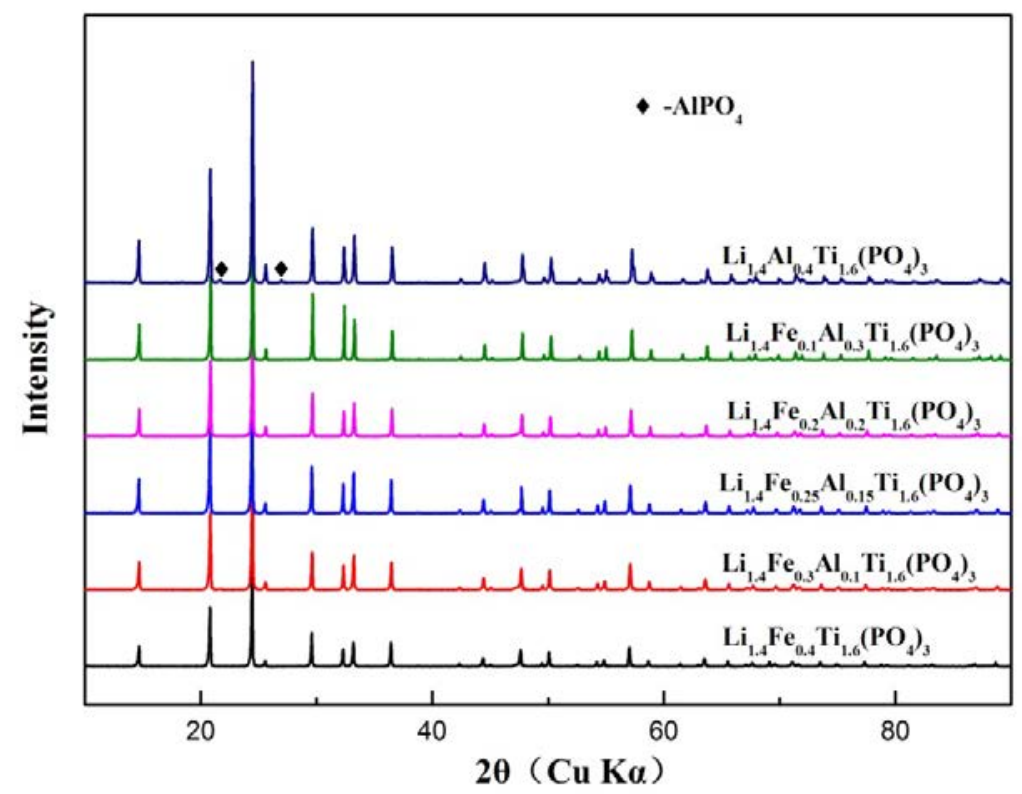


Fig. 5

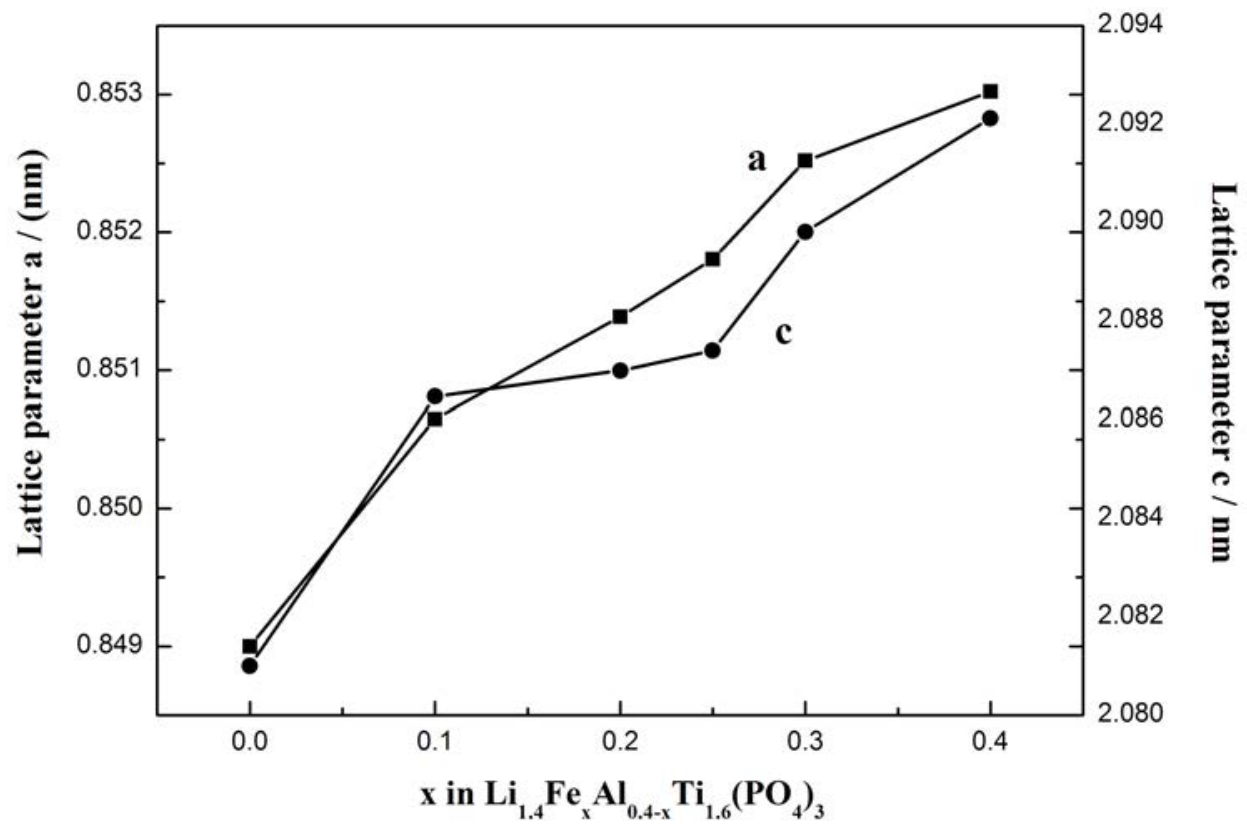


Fig. 6

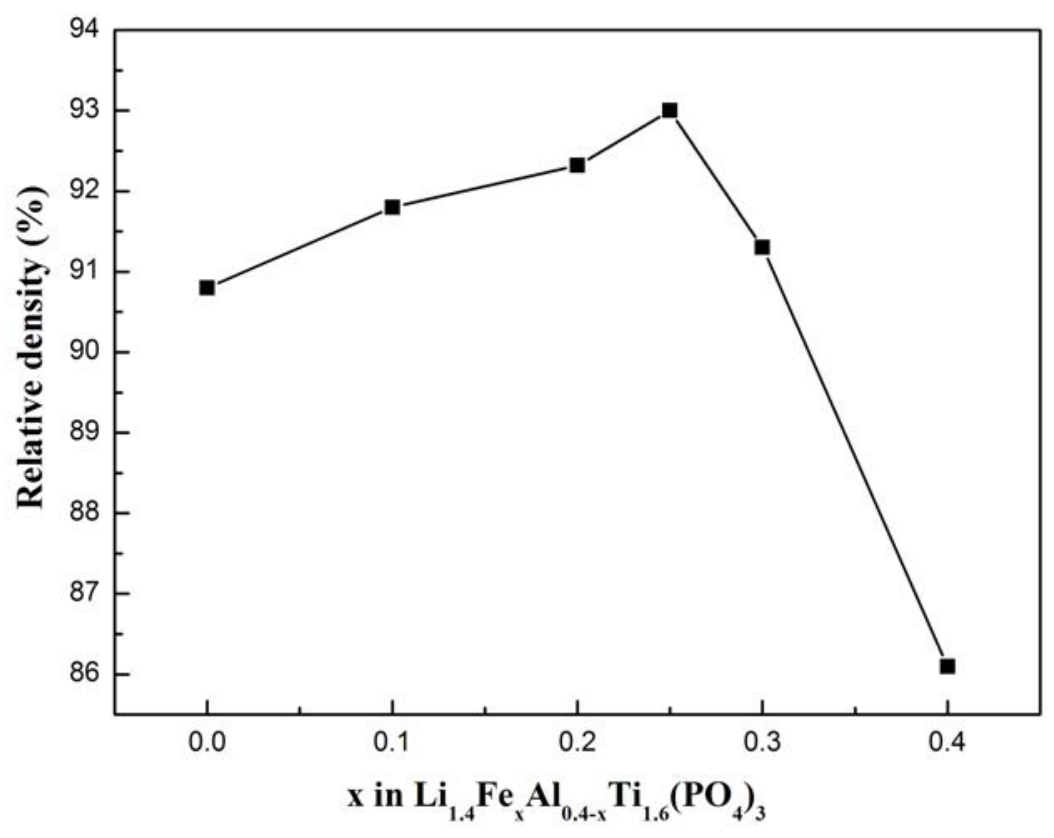


Fig. 7
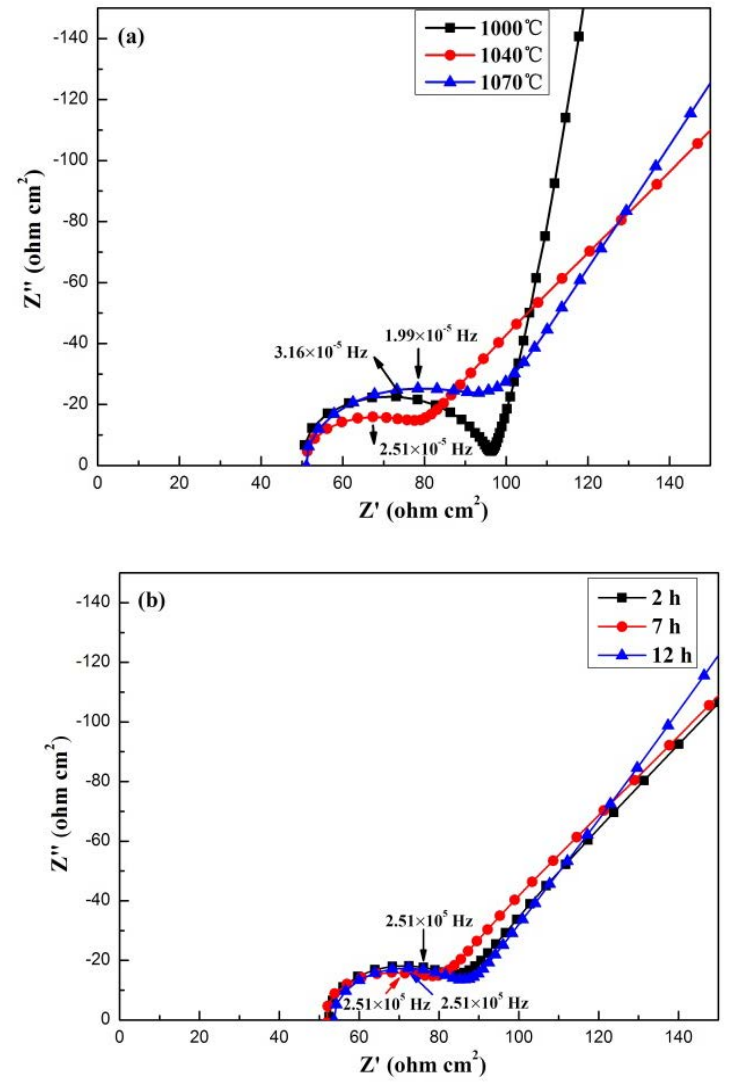
Fig. 8

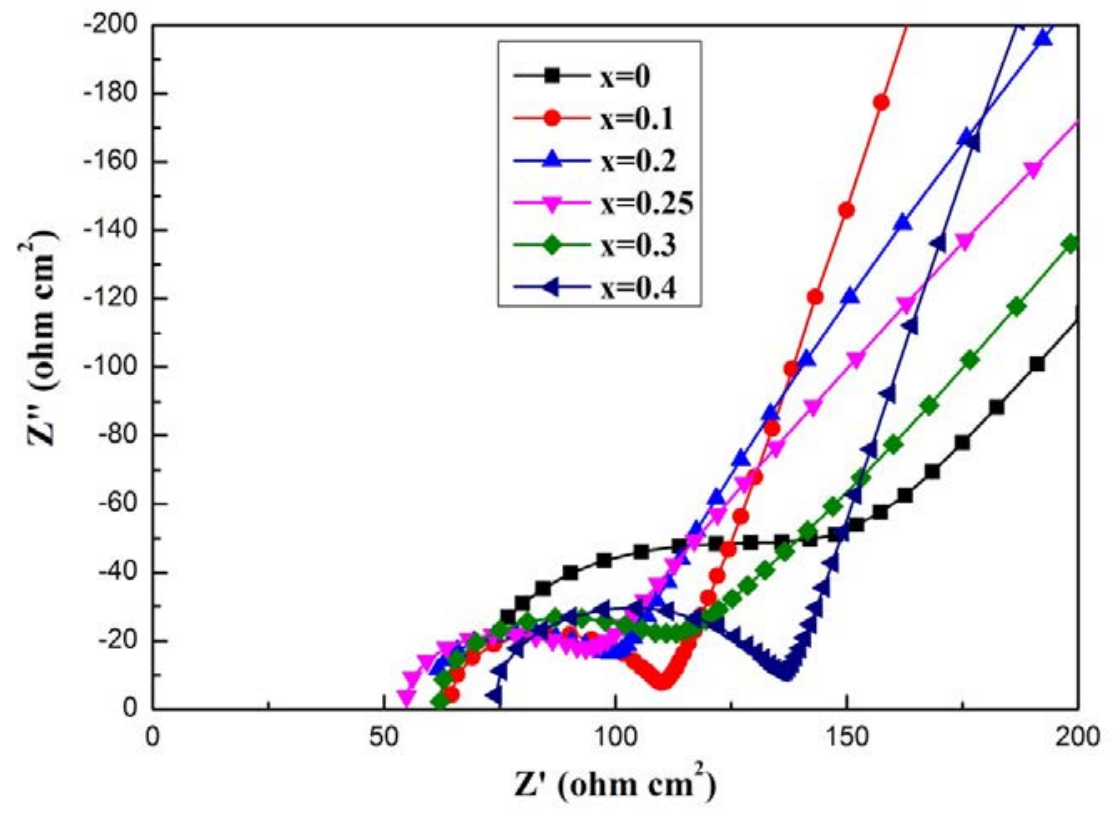


Fig. 9

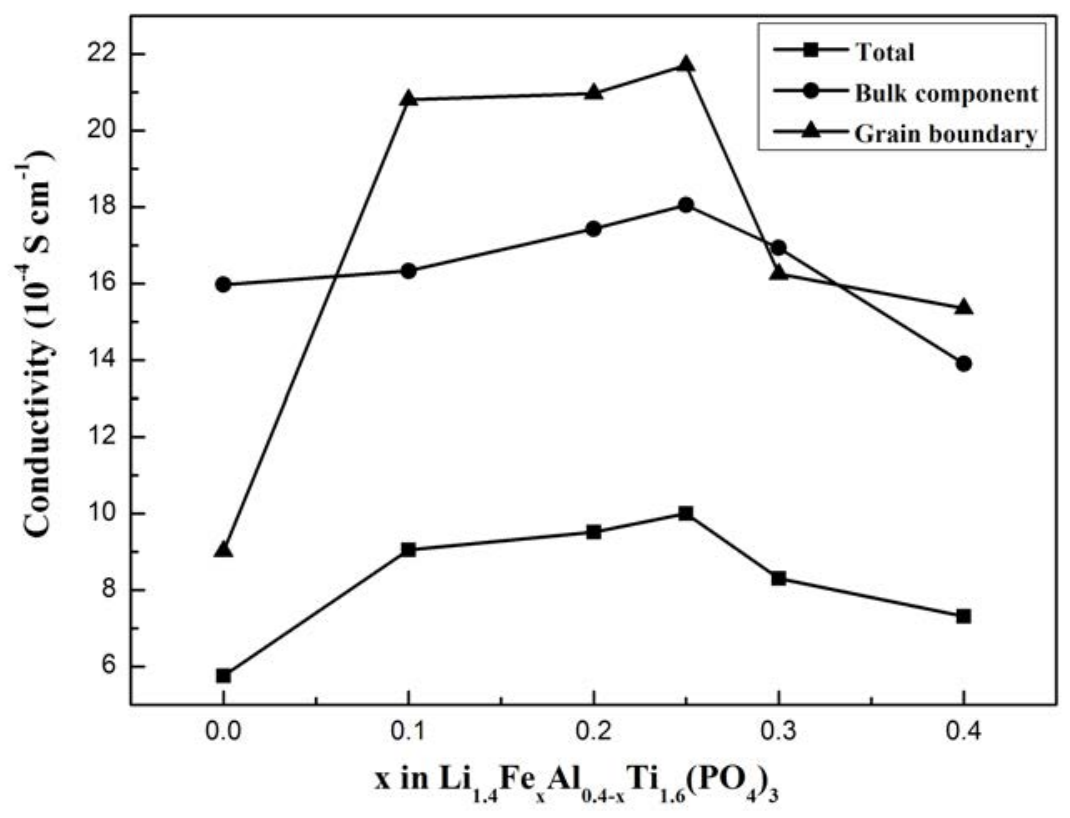


Fig. 10

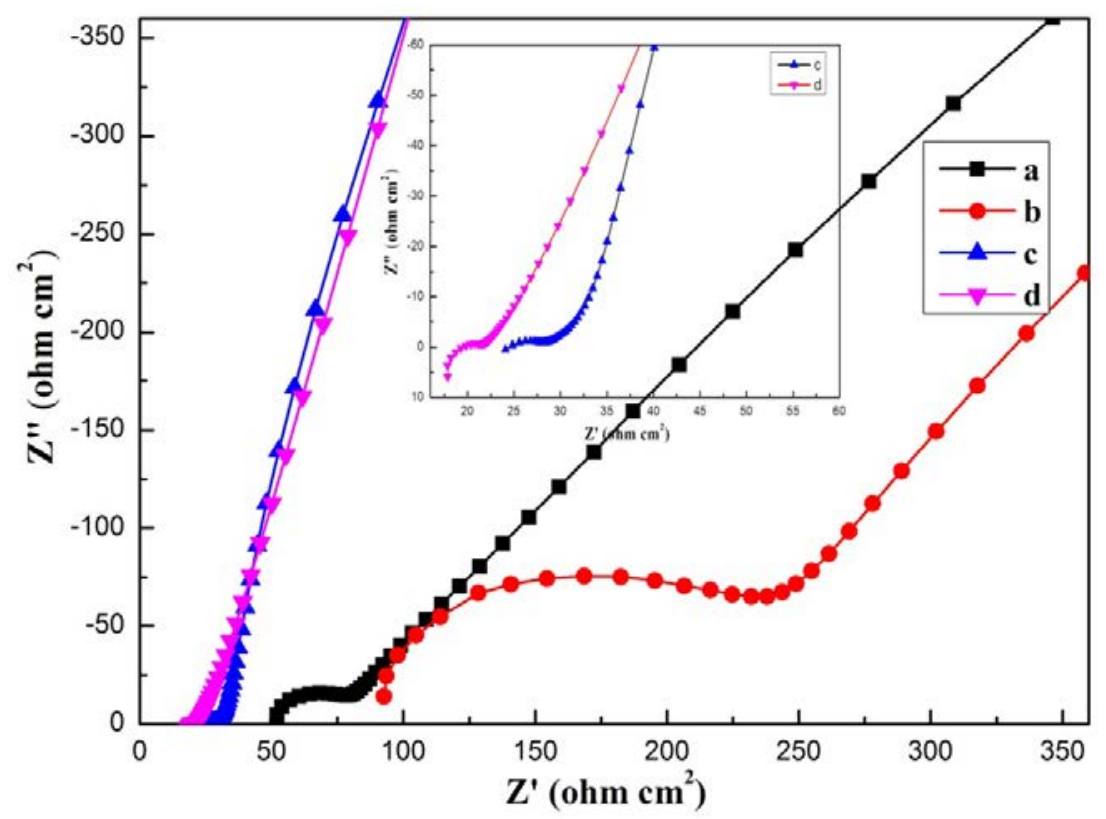


Fig. 11

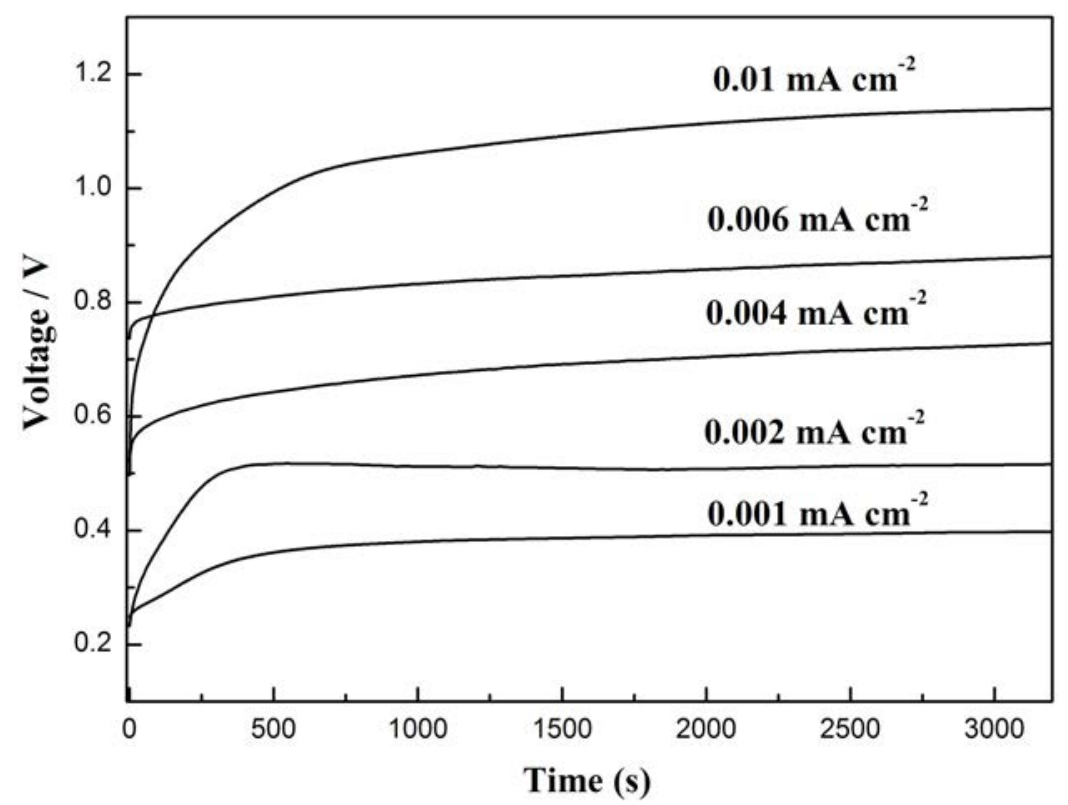


Fig. 12

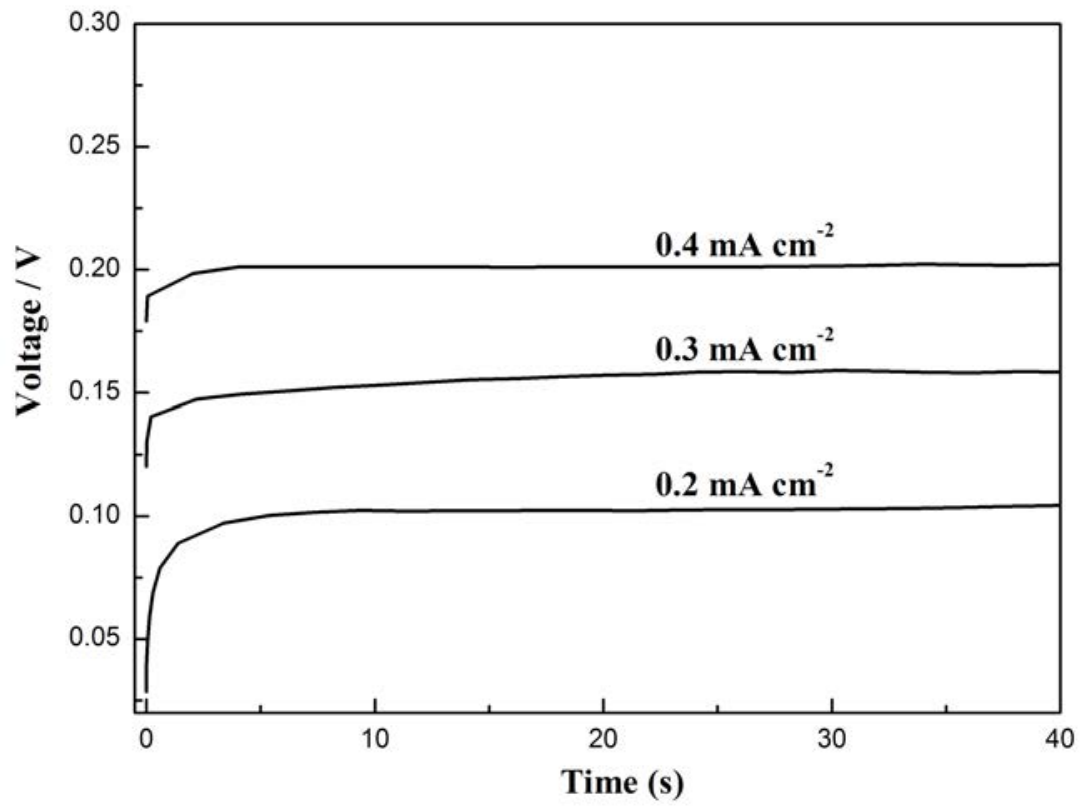

